\title{
Analisis Energi Gelombang Air Laut Menggunakan Teknologi Oscillating Water Column
}

\author{
${\text { Muhammad Rifki Azizie }{ }^{1} \text {, Darma Arif Wicaksono }{ }^{1} \text {, Fitriana }}^{1}$ \\ ${ }^{1}$ Teknik Elektro, Fakultas Teknik, Universitas Muhammadiyah Jember \\ Jl. Karimata No. 49 Jember 68121 \\ E-mail: rifkiazizie1998@gmail.com
}

\begin{abstract}
ABSTRAK
Abstrak - Indonesia mempunyai potensi di bidang kemaritiman yang sangat besar, terdiri dari 17.480 pulau, dengan wilayah maritim yang diukur hampir $6.000 .000 \mathrm{~km}^{2}$. Pemanfaatan energi kelautan sayangnya belum dimanfaatkan secara optimal khususnya dalam membangkitkan tenaga listrik. Melihat permasalahan tersebut, maka pada penelitian ini membahas tentang analisis perhitungan potensi energi hasil perhitungan tenaga gelombang laut dengan menggunakan sistem kolom air berosilasi di perairan Indonesia. Sistem ini dipilih karena output energi listrik dianggap lebih stabil dan sesuai dengan wilayah perairan Indonesia. Penelitian dimulai dari pengumpulan data sekunder yang berupa literatur dari berbagai sumber, kemudian data dianalisis menggunakan berbagai persamaan untuk menghitung periode gelombang, panjang gelombang, kecepatan gelombang, energi total serta energi densitas pada prototype potensi gelombang air laut, Berdasar hasil analisa perhitungan menggunakan persamaan yang ada dengan percobaan lima kali dengan variasi tinggi gelombang yang berbeda mendapatkan energi paling rendah 1,27 Joule dan paling besar 30,02 Joule, serta analisa pada energi densitasnya paling rendah sebesar 2,42 Joule/ $\mathrm{m}^{2}$ dan serta analisa pada energi densitasnya paling besar 20,02 Joule/ $\mathrm{m}^{2}$ dengan hasil penelitian tersebut dapat disimpulkan bahwa rata - rata tinggi gelombang sangat mempengaruhi periode gelombang, panjang gelombang, kecepatan gelombang, energi total dan energi densitasnya.
\end{abstract}

Kata kunci: Oscillating Water Column (OWC), Potensi Energi Total, Potensi Energi Laut.

Copyright @ 2019 Universitas Muhammadiyah Jember.

\section{PENDAHULUAN}

Seiring dengan adanya pertumbuhan penduduk, pembangunan dan pengembangan wilayah di dunia mengakibatkan peningkatan jumlah kebutuhan manusia akan energi listrik. Selama ini sumber daya yang dipakai pembangkit listrik untuk memenuhi kebutuhan manusia kebanyakan berasal dari sumber daya tak terbarukan, yang berbahan bakar fosil seperti minyak bumi dan batu bara. Pemanfaatan potensi energi kelautan sayangnya hingga saat ini belum banyak diketahui oleh berbagai pihak salah satunya adalah Asosiasi Energi Laut Inonesia ASELI, Beberapa daerah dengan ketinggian gelombang lebih dari 2 meter dan priode dalam 10 detik adalah gelombang potensial untuk pengembangan energi terbarukan [1].

Prinsip Kerja teknologi pengkonversi energi gelombang laut menjadi energi listrik yaitu mengakumulasi energi gelombang laut yang digunakan untuk menggerakkan turbin, Adanya hal tersebut menjadi sangat penting digunakan sebagai salah satu bahan acuan untuk memilih suatu wilayah yang secara topografi mepunyai kemungkinan besar akumulsai energi.Penelitian sampai sekarang masih terus dilakukan guna mendapatkan hasil yang paling baik untuk ditetapkan [2]. Namun ada salah satu tekhnologi alternatif untuk pembangunan ( PLTGL ) Pembangkit Listrik Tenaga Gelombang Laut dengan output energi yang stabil yaitu teknologi Oscillating Water Column, Oscillating water column adalah salah satu teknologi pada pembangkit listrik yang menggunakan tenaga naik turunnya air gelombang laut sebagai penggerak turbin [3].

\section{KAJIAN PUSTAKA}

2.1. Teknik Konversi Energi Gelombang Menjadi Energi Listrik

Ada tifa cara membangkitkan listrik dengan tenaga gelombang air laut, yaitu :

\subsubsection{Sistem Oscillating Water Column}

Energi kinetik yang ada pada gelombang air laut digunakan untuk mengerakkan turbin. gelombang naik ke dalam ruangan chamber selanjutnya air yang naik akan menekan udara keluar dari ruang chamber dan akan menyebabkan turbin berputar ketika air turun, udara bertiup 
dari luar ke dalam ruang chamber dan memutar turbin kembali [4]. Untuk lebih jelasnya dapat dilihat pada gambar 1 dibawah ini.

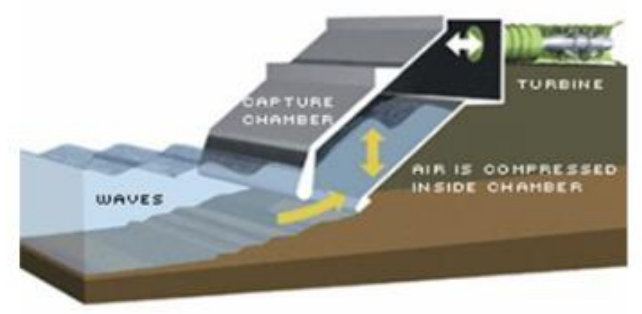

Gambar 1. Sistem Oscillating Water Column ( OWC)

\subsubsection{Pasang Surut Air Laut}

Bentuk lain dari pemanfaatan energi gelombang laut adalah energi pasang surut. Ketika air pasang datang ke pantai, air pasang akan ditampung di dalam kolam reservoir. Kemudian ketika air surut, air yang ada dibelakang reservoir dapat dialirkan seperti prinsip kerja PLTA biasa seperti terlihat pada gambar 2. Agar sistem bekerja secara optimal, maka kita membutuhkan gelombang pasang yang besar, dibutuhkan perbedaan kira-kira 16 kaki antara gelombang pasang dan gelombang surut. Hanya ada beberapa tempat yang memiliki kriteria tersebut. Beberapa pembangkit listrik telah beroperasi menggunakan sistem ini. Sebuah pembangkit listrik di Prancis sudah beroperasi dan mencukupi kebutuhan listrik untuk 240.000 rumah [5].

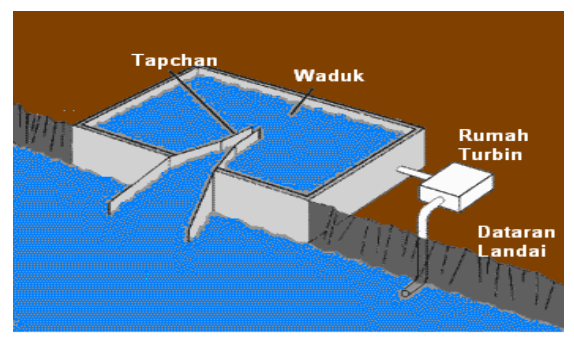

Gambar 2. Menggunakan Sistem Pasang Surut Air Laut

\subsubsection{Pemanfaatan Perbedaan Suhu Air Laut}

Cara lain untuk membangkitkan listrik dengan gelombang air laut adalah dengan memanfaatkan perbedaan suhu di laut. Jika kita berenang dan menyelam kita akan merasakan bahwa semakin kita menyelam maka suhu air laut akan semakin rendah (dingin). Suhu yang lebih tinggi pada permukaan laut disebabkan oleh sinar matahari sehingga memanasi permukaan laut [6]. Tetapi, di bawah permukaan laut suhunya sangat dingin. Sistem dengan pemanfaatan perbedaan suhu air laut dapat kita lihat pada gambar 3.

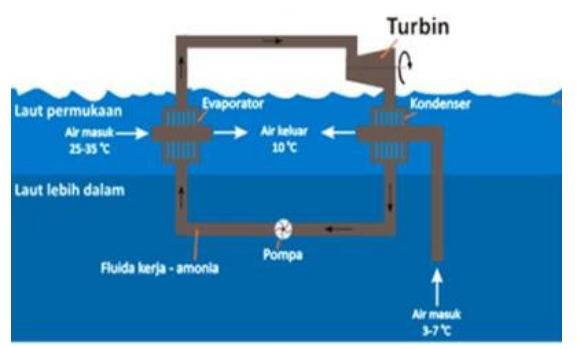

Gambar 3. Menggunakan Sistem Perbedaan Suhu Air Laut 


\subsection{Analisa Perhitungan Pada Prototype}

Pada Periode gelombang laut dipengaruhi oleh panjang dan kecepatan gelombang Berdasar rata-rata tinggi gelombang pada prototype dapat diketahui hasil hitungan besarnya periode gelombang datang. rumus yang dipakai menggunakan rumus yang disarankan oleh Kim Nielsen (1986), yaitu :

$$
\mathrm{T}: 3,55 \sqrt{H}
$$

\section{$\mathrm{T}:$ Periode $(\mathrm{s})$}

H: Tinggi Gelombang ( $\mathrm{m}$ )

Setelah mengetahui prakiraan periode gelombang datang, maka langkah - langkah selanjutnya adalah menghitung besar panjang dan kecepatan gelombang yang disarankan oleh David Ross (1980), sebagai berikut :

$$
\mathrm{V}: \frac{\lambda}{\mathrm{T}}
$$

$\mathrm{V}:$ Kecepatan gelombang $(\mathrm{m} / \mathrm{s})$

$\mathrm{T}:$ Periode (s)

$\lambda$ : Panjang gelombang $(\mathrm{m})$

Setelah mengetahui kecepatan gelombang datang, maka langkah selanjutnya adalah menghitung energi potensial dan kinetik dengan menggunakan persamaan sebagai berikut :

$$
\text { P.E }=\operatorname{mg} \frac{y(x, t)}{2}(\mathrm{j})
$$

Dimana :

$\mathrm{m}:$ w $\rho y$ : massa gelombang $(\mathrm{kg})$

$\rho:$ massa jenis air laut $\left(1 \mathrm{~kg} / \mathrm{m}^{3}\right)$

$w$ : lebar chamber OWC ( $0,38 \mathrm{~m})$

$\mathrm{Y}: \mathrm{y}(\mathrm{x}, \mathrm{t})=\mathrm{a} \sin (\mathrm{kx}-\omega \mathrm{t})(\mathrm{m})$ (di asumsikan sama dengan luas chamber pada OWC).

$\mathrm{a}: \mathrm{h} / 2:$ amplitudo gelombang.

$\mathrm{h}:$ ketinggian rata - rata gelombang $(\mathrm{m})$

$\mathrm{k}: \frac{2 \pi}{\lambda}:$ konstanta gelombang.

$\lambda:$ panjang gelombang.

$\omega: \frac{2 \pi}{\mathrm{T}}(\mathrm{rad} / \mathrm{sec}):$ frekuensi gelombang.

$\mathrm{T}$ : Periode Gelombang ( $\mathrm{s}$ )

Maka persamaan energi potensial ini dapat ditulis sebagai berikut :

$$
\text { P.E. }=\mathrm{w} \rho g \frac{y^{2}}{2}=\mathrm{w} \rho g \frac{a^{2}}{2} \sin ^{2}(\mathrm{kx}-\omega \mathrm{t})
$$

Selanjutnya dihitung besarnya energi potensial gelombang lebih dari 1 periode, di asumsikan bahwa gelombang hanya merupakan fungsi dari x terhadap waktu, sehingga didapatkan persamaan $\mathrm{y}=(\mathrm{x}, \mathrm{t}-\omega \mathrm{t}) \mathrm{dx}$ Jadi didapatkan :

$$
\text { dP.E. }=0,5 \mathrm{w} \rho g a^{2} \sin ^{2}(\mathrm{kx}-\omega \mathrm{t}) \mathrm{dx}
$$

Berdasarkan persamaan $\mathrm{k}=: \frac{2 \pi}{\lambda}$ dan $\omega=\frac{2 \pi}{\lambda}$, maka didapatkan persamaan :

$$
\text { P.E. }=\frac{1}{4} \mathrm{w} \rho g a^{2} \lambda(\mathrm{J})
$$

Besarnya energi kinetik lebih dari satu periode adalah sebanding dengan besarnya energi potensial yang dihasilkan. 


$$
\text { K.E. }=\frac{1}{4} \mathrm{w} \rho g a^{2} \lambda(\mathrm{J})
$$

Dimana energi kinetik adalah bagian energi yang berhubungan dengan gerakan dari gelombang laut, setelah besarnya energi potensial dan kinetik diketahui, maka dapat dihitung total energi yang di hasilkan dalam satu periode dapat dicari menggunakan persamaan :

$$
E_{w}=\frac{1}{2} \cdot \mathrm{w} \cdot \rho \cdot \mathrm{g} \cdot a^{2} \cdot \lambda(\mathrm{J})
$$

Energi Total yang dimaksud di sini adalah jumlah besarnya energi yang dihasilkan gelombang air laut yang didapatkan melalui penjumlahan energi potensial dan energi kinetik yang dimilikinya, melalui persamaan diatas maka dapat dihitung besarnya energi Density atau energi densitasnya $E_{W D}$ sebagai berikut.

$$
E_{W D}=\frac{E w}{\lambda w}=\frac{1}{2} \cdot \rho \cdot \mathrm{g} \cdot a^{2} \cdot\left(\mathrm{J} / m^{2}\right)
$$

\section{METODE PENELITIAN}

\subsection{Prosedur Penelitian}

\subsubsection{Studi Literatur Terhadap Objek Dan Penelitian}

Pada tahap ini adalah proses menggali dan mempelajari materi yang didapat jurnal-jurnal, buku atau artikel baik lokal maupun internasional demi menunjang penelitian ini, yang nanti akan dijadikan sebagai rujukan untuk menentukan hipotesis awal penelitian.

\subsubsection{Perancangan Prototype}

Pada tahap ini akan melakukan pembuatan Prototype, dimana pertama-tama membuat ukuran Prototype serta membuat perangkat keras kontrol motor dengan komponen- komponen yang sudah disiapkan.

\subsubsection{Pengujian Prototype}

Pada tahap ini Prototype yang telah selesai dirancang maka akan melakukan pengujian untuk mengetahui kinerja Prototype sehingga dapat menunjang saat melakukan pengambilan data.

\subsubsection{Analisa Data}

Pada tahap ini setelah melakukan pengujian pada prototype selanjutnya data akan dianalisa untuk mengetahui hasil pengujian pada prototype.

\subsubsection{Penarikan Kesimpulan}

Pada tahap ini semua pengujian data yang telah diperoleh dan yang telah dianalisa akan simpulkan.

\subsection{Perancangan Perangkat Keras}

Bagian mekanik merupakan bagian nyata dari bentuk alat rancang bangun konversi tenaga listrik gelombang air laut menggunakan metode Oscillating Water Column ini, bahan utama untuk pembuatan Prototype adalah kaca yang di desain menjadi sebuah kolam untuk simulasi gelombang laut. Adapun pembuatan mekanik Prototype ini seperti gambar 4 sebagai berikut:

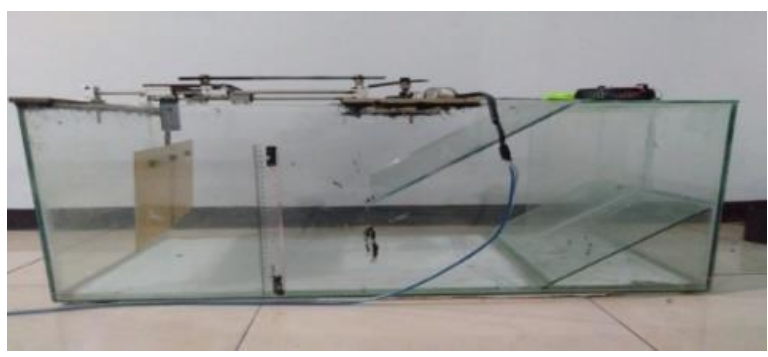

Gambar 4. Perancangan Perangkat Keras 


\subsection{Perancangan Perangkat Lunak}

Pada saat alat di jalankan power supply $12 \mathrm{~V}$ menyuplai tegangan pada Arduino dan keadaan arduino aktif, selanjutnya arduino memproses masukkan program yang telah dibuat, selanjutnya arduino mengeluarkan sinyal PWM dan memerintahkan motor driver untuk memberikan tegangan kepada Power Window, selanjutnya akan power window berputar dan papan pendorong yang di pasang di besi panjang akan bergerak maju dan mundur dengan demikian gelombang buatan pada prototype akan di dapatkan, Selanjutnya air yang di dorong oleh papan akan diteruskan ke chamber atau ruangan kolom udara, dengan mengetahui rata - rata tinggi gelombang yang di hasilkan oleh gerakan motor dapat dihitung dengan persamaan - persamaan yang ada di atas sehingga dapat mengetahui berapa periode gelombang, panjang gelombang, kecepatan gelombang, energi total serta energi densitasnya.

\subsection{Prinsip Kerja Sistem}

Pertama power supply menyuplai tegangan dan arus pada mikrokontroler sehingga mikrokontroler memproses perintah yang telah program, selanjutnya mikrokontroler memberikan sinyal berupa PWM untuk menggerakan motor power window dengan menarik papan pendorong air dengan kecepatan yang bervariasi untuk mendapatkan variasi tinggi gelombang, Prinsip kerja prototype menggunakan metode $O W C$ adalah mencari data rata-rata tinggi gelombang air laut dengan skala prototype untuk dihitung berapa besar energi berdasarkan persamaan - persamaan diatas, gelombang yang datang dari papan pendorong akan menabrak batas kaca dan masuk kedalam chamber dimana pada bagian bawah chamber ini terdapat kolom terbuka untuk masuknya air , berdasarkan data inputan dari rata-rata gelombang sehingga dapat dihitung menggunakan persamaan - persamaan yang ada diatas, dengan mengetahui rata-rata tinggi gelombang maka dapat dihitung periode gelombang, panjang gelombang, kecepatan gelombang, energi total serta energi densitas nya. Untuk mempermudah dalam memahami cara kerja secar keseluruhan sistem, dapat dilihat pada gambar 5 berikut.

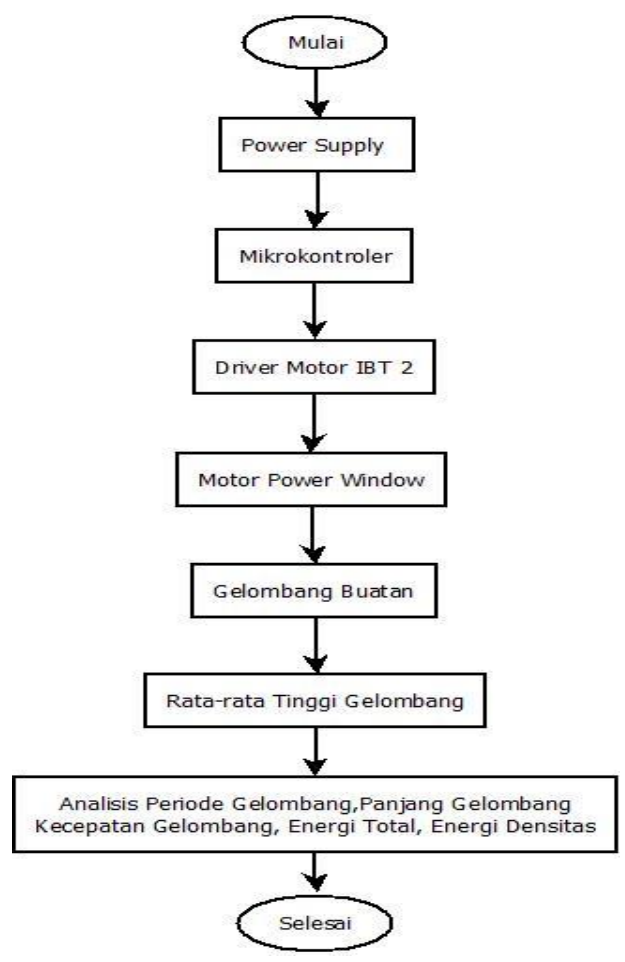

Gambar 5. Prinsip Kerja Sistem 


\section{HASIL DAN PEMBAHASAN}

\subsection{Pengujian Motor Power Window}

Pada pengujian Motor Power Window bertujuan untuk mengetahui kerja dari motor power window dan untuk mengetahu apakah output dari driver motor IBT 2 sesuai dengan kecepatan PWM yang diprogram pada software arduino IDE, Pengujian dilakukan dengan cara menghubungkan kabel motor power window pada coil driver IBT. Prosedur pengujian motor power window pada langkah dan tabel 1 berikut ini :

1. Hubungkan kabel motor power window pada coil driver IBT 2.

2. Hidupkan switch sistem kontrol yang telah dirancang.

3. Catat hasil tinggi gelombang pada prototype.

4. Hitung rata rata tinggi gelombang pada prototype

Tabel 1. Pengujian Motor Power Window Terhadap Rata-Rata Tinggi Gelombang.

\begin{tabular}{|c|c|c|c|c|c|c|c|c|c|c|}
\hline \multirow{2}{*}{ No } & \multicolumn{2}{|c|}{ Parameter } & \multirow{2}{*}{\multicolumn{7}{|c|}{ Output Tinggi Gelombang ( $\mathrm{cm}$ ) }} & \multirow{2}{*}{$\begin{array}{c}\text { Rata-Rata } \\
\text { Tinggi } \\
(\mathrm{cm})\end{array}$} \\
\hline & $\mathbf{V}(\mathbf{m} / \mathbf{s})$ & $\begin{array}{c}\mathbf{T} \\
(\mathbf{s})\end{array}$ & & & & & & & & \\
\hline \multirow{3}{*}{1} & \multirow{3}{*}{170} & \multirow{3}{*}{20} & H1 & $\mathbf{H 2}$ & H3 & H4 & H5 & H6 & H7 & \multirow{3}{*}{1,55} \\
\hline & & & $\begin{array}{c}1 \\
\text { H8 }\end{array}$ & 1,4 & 1,8 & 2 & 2,3 & 2,7 & 3 & \\
\hline & & & 3,4 & & & & & & & \\
\hline \multirow{5}{*}{2} & \multirow{5}{*}{180} & \multirow{5}{*}{30} & H1 & H2 & H3 & H4 & H5 & H6 & H7 & \multirow{5}{*}{3,35} \\
\hline & & & 1,3 & 1,6 & 2 & 2,2 & 2,5 & 2,8 & 3,2 & \\
\hline & & & H8 & H9 & H10 & H11 & H12 & H13 & H14 & \\
\hline & & & 3,5 & 3,7 & 3,9 & 4,2 & 4,5 & 4,7 & 5 & \\
\hline & & & $\begin{array}{c}\mathbf{H 1 5} \\
5,2\end{array}$ & & & & & & & \\
\hline \multirow{5}{*}{3} & \multirow{5}{*}{190} & \multirow{5}{*}{40} & H1 & H2 & H3 & H4 & H5 & H6 & H7 & \multirow{5}{*}{4,48} \\
\hline & & & 1,6 & 2 & 2,4 & 2,7 & 3 & 3,3 & 3,7 & \\
\hline & & & H8 & H9 & H10 & H11 & H12 & H13 & H14 & \\
\hline & & & 4 & 4,3 & 4,5 & 4,8 & 5 & 5,1 & 5,3 & \\
\hline & & & H15 & H16 & H17 & H18 & H19 & H20 & H21 & \\
\hline \multirow{13}{*}{4} & \multirow{13}{*}{200} & \multirow{13}{*}{50} & 5,5 & 5,7 & 6 & 6,2 & 6,4 & 6,7 & 7 & \multirow{13}{*}{5,57} \\
\hline & & & H22 & H23 & H24 & & & & & \\
\hline & & & 7,2 & 7,5 & 7,5 & & & & & \\
\hline & & & H1 & H2 & H3 & H4 & H5 & H6 & H7 & \\
\hline & & & 1,6 & 2 & 2,5 & 2,8 & 3,2 & 3,5 & 3,7 & \\
\hline & & & H8 & H9 & H10 & H11 & H12 & H13 & H14 & \\
\hline & & & 3,9 & 4,2 & 4,5 & 4,7 & 4,7 & 5 & 5,3 & \\
\hline & & & H15 & H16 & H17 & H18 & H19 & H20 & H21 & \\
\hline & & & 5,5 & 5,7 & 4,7 & 5,9 & 6 & 6,3 & 6,5 & \\
\hline & & & H22 & H23 & H24 & H25 & H26 & H27 & H28 & \\
\hline & & & 6,5 & 6,7 & 6,9 & 7 & 7,3 & 7,6 & 7,8 & \\
\hline & & & H29 & H30 & H31 & H32 & H33 & & & \\
\hline & & & 8 & 8,2 & 8,5 & 8,7 & 8,7 & & & \\
\hline \multirow{12}{*}{5} & \multirow{12}{*}{210} & \multirow{12}{*}{60} & H1 & H2 & H3 & H4 & H5 & H6 & $\mathbf{H 7}$ & \multirow{12}{*}{6,36} \\
\hline & & & 1,8 & 2,2 & 2,5 & 2,8 & 3,2 & 3,5 & 3,7 & \\
\hline & & & H8 & H9 & H10 & H11 & H12 & H13 & H14 & \\
\hline & & & 4,1 & 4,4 & 4,7 & 4,8 & 5 & 5,2 & 5,5 & \\
\hline & & & H15 & H16 & H17 & H18 & H19 & H20 & H21 & \\
\hline & & & 5,7 & 5,7 & 6 & 6,3 & 6,5 & 6,5 & 6,7 & \\
\hline & & & H22 & H23 & H24 & H25 & H26 & H27 & H28 & \\
\hline & & & 7 & 7,2 & 7,2 & 7,5 & 7,6 & 7,8 & 8 & \\
\hline & & & H29 & H30 & H31 & H32 & H33 & H34 & H35 & \\
\hline & & & 8,2 & 8,2 & 8,5 & 8,6 & 8,8 & 8,8 & 8,8 & \\
\hline & & & H36 & H37 & H38 & H39 & H40 & & & \\
\hline & & & 8,9 & 9,1 & 9,3 & 9,3 & 9,3 & & & \\
\hline
\end{tabular}

Pada tabel 1. Pengujian motor power window terhadap rata rata tingi gelombang dapat dilihat bahwa dengan 170 mendapatkan rata-rata tinggi gelombang pada prototype sebesar $2,2 \mathrm{~cm}$, pada kecepatan 190 mendapatkan rata-rata tinggi gelombang sebesar 4,48 cm, pada kecepatan 210 
mendapatkan rata-rata tinggi gelombang sebesar $6,36 \mathrm{~cm}$, pada kecepatan 200 mendapatkan ratarata tinggi gelombang sebesar $5,57 \mathrm{~cm}$ dan pada kecepatan 210 mendapatkan rata-rata tinggi gelombang sebesar $6,36 \mathrm{~cm}$, Jadi dapat disimpulkan bahwa kecepatan motor terhadap rata - rata tinggi gelombang berbanding lurus, Semakin tinggi kecepatan motor maka hasil rata-rata tinggi gelombang juga semakin besar.

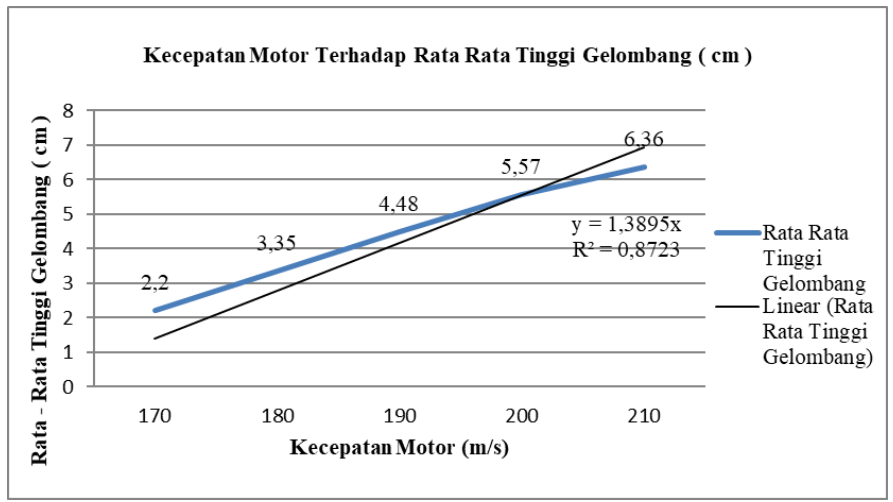

Gambar 6. Grafik Kecepatan Motor Terhadap Tinggi Gelombang Pada Prototyoe.

\subsection{Analisa Gelombang pada Prototype}

Analisa Periode gelombang, panjang gelombang, kecepatan gelombang dan energi total serta energi densitasnya pada prototype potensi gelombang air laut menggunakan OWC bertujuan untuk mengetahui hasil analisis periode gelombang, panjang gelombang, kecepatan, energi pada prototype. berikut hasil analisis dengan rata-rata tinggi gelombang.

Tabel 2. Hasil Analisis Rata-Rata Tinggi Gelombang 2,2 cm

\begin{tabular}{llcc}
\hline No & \multicolumn{1}{c}{ Parameter } & Hasil Perhitungan & Satuan \\
\hline 1 & Periode Gelombang & 0,52 & $\mathrm{~s}$ \\
2 & Panjang Gelombang & 1,38 & $\mathrm{~m}$ \\
3 & Kecepatan & 2,36 & $\mathrm{~m} / \mathrm{s}$ \\
& Gelombang & & \\
4 & Energi Kinetik & 0,63 & $\mathrm{Joule}$ \\
5 & Energi Potensial & 0,63 & $\mathrm{~J}$ oule \\
6 & Energi Total & 1,27 & $\mathrm{~J}$ oule \\
7 & Energi Density & 2,42 & $\mathrm{~J} / \mathrm{m}^{2}$ \\
\hline
\end{tabular}

Tabel 3. Hasil Analisis Rata-Rata Tinggi Gelombang 3,35 cm

\begin{tabular}{llcc}
\hline No & \multicolumn{1}{c}{ Parameter } & Hasil Perhitungan & Satuan \\
\hline 1 & Periode Gelombang & 0,66 & $\mathrm{~S}$ \\
2 & Panjang Gelombang & 2,20 & $\mathrm{M}$ \\
3 & Kecepatan Gelombang & 3,33 & $\mathrm{~m} / \mathrm{s}$ \\
4 & Energi Kinetik & 2,53 & $\mathrm{~J}$ oule \\
5 & Energi Potensial & 2,53 & $\mathrm{Joule}$ \\
6 & Energi Total & 5,06 & $\mathrm{Joule}$ \\
7 & Energi Density & 6,06 & $\mathrm{~J} / \mathrm{m}^{2}$ \\
\hline
\end{tabular}


Tabel 4. Hasil Analisis Rata-Rata Tinggi Gelombang 4,48 cm

\begin{tabular}{llcc}
\hline No & \multicolumn{1}{c}{ Parameter } & Hasil Perhitungan & Satuan \\
\hline 1 & Periode Gelombang & 0,75 & $\mathrm{~S}$ \\
2 & Panjang Gelombang & 2,86 & $\mathrm{M}$ \\
3 & Kecepatan Gelombang & 3,81 & $\mathrm{~m} / \mathrm{s}$ \\
4 & Energi Kinetik & 5,49 & $\mathrm{Joule}$ \\
5 & Energi Potensial & 5,49 & $\mathrm{Joule}$ \\
6 & Energi Total & 10,90 & $\mathrm{Joule}$ \\
7 & Energi Density & 10,104 & $\mathrm{~J} / \mathrm{m}^{2}$ \\
\hline
\end{tabular}

Tabel 5. Hasil Analisis Rata-Rata Tinggi Gelombang 5,57 cm

\begin{tabular}{llcc}
\hline No & \multicolumn{1}{c}{ Parameter } & $\begin{array}{c}\text { Hasil } \\
\text { Perhitungan }\end{array}$ & Satuan \\
\hline 1 & Periode Gelombang & 0,83 & $\mathrm{~s}$ \\
2 & Panjang Gelombang & 3,48 & $\mathrm{~m}$ \\
3 & Kecepatan Gelombang & 4,19 & $\mathrm{~m} / \mathrm{s}$ \\
4 & Energi Kinetik & 10,35 & $\mathrm{Joule}$ \\
5 & Energi Potensial & 10,35 & $\mathrm{Joule}$ \\
6 & Energi Total & 20,71 & $\mathrm{Joule}$ \\
7 & Energi Density & 16,66 & $\mathrm{~J} / \mathrm{m}^{2}$ \\
\hline
\end{tabular}

Tabel 6. Hasil Analisis Rata-Rata Tinggi Gelombang 6,36 cm

\begin{tabular}{llcc}
\hline No & \multicolumn{1}{c}{ Parameter } & $\begin{array}{c}\text { Hasil } \\
\text { Perhitungan }\end{array}$ & Satuan \\
\hline 1 & Periode Gelombang & 0,89 & $\mathrm{~s}$ \\
2 & Panjang Gelombang & 4,04 & $\mathrm{~m}$ \\
3 & Kecepatan Gelombang & 4,80 & $\mathrm{~m} / \mathrm{s}$ \\
4 & Energi Kinetik & 15,51 & $\mathrm{Joule}$ \\
5 & Energi Potensial & 15,51 & Joule \\
6 & Energi Total & 31,02 & $\mathrm{Joule}$ \\
7 & Energi Density & 20,20 & $\mathrm{~J} / \mathrm{m}^{2}$ \\
\hline
\end{tabular}

Dapat dilihat pada tabel 2 sampai 6 diatas bahwa pada saat perhitungan periode gelombang, panjang gelombang, kecepatan gelombang, energi total serta energi densitasnya pada prototype dengan menggunakan masukkan data berupa rata - rata tinggi gelombang yang di hasilkan oleh pergerakan motor sebagai gelombang buatan, hasil analisis periode gelombang, kecepatan gelombang, panjang gelombang, energi kinetik dan potensial, energi total serta energi densitasnya berbanding lurus dengan rata - rata tinggi gelombang. 


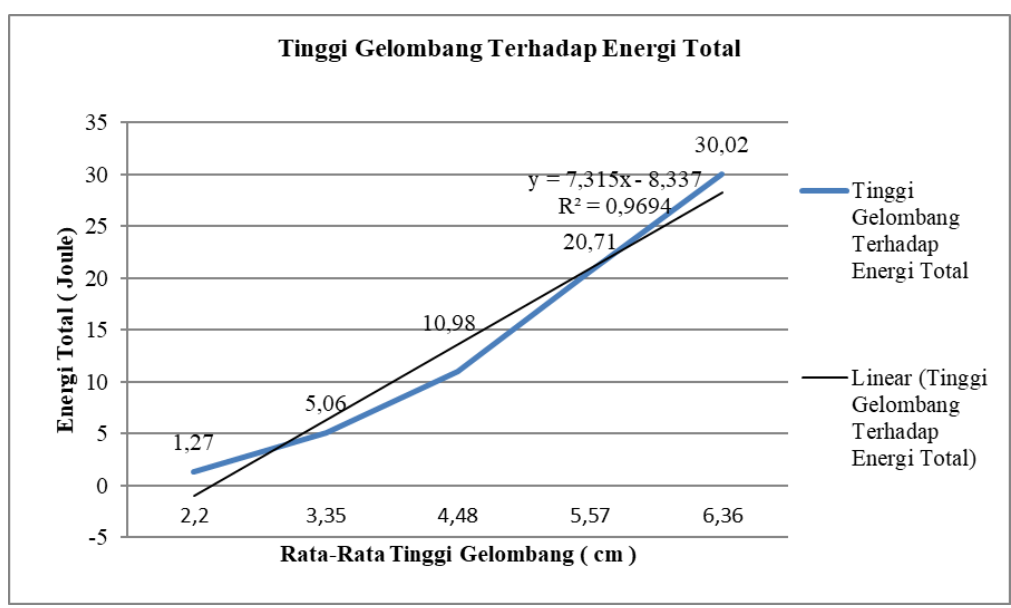

Gambar 6. Rata-Rata Tinggi Gelombang Terhadap Energi Total

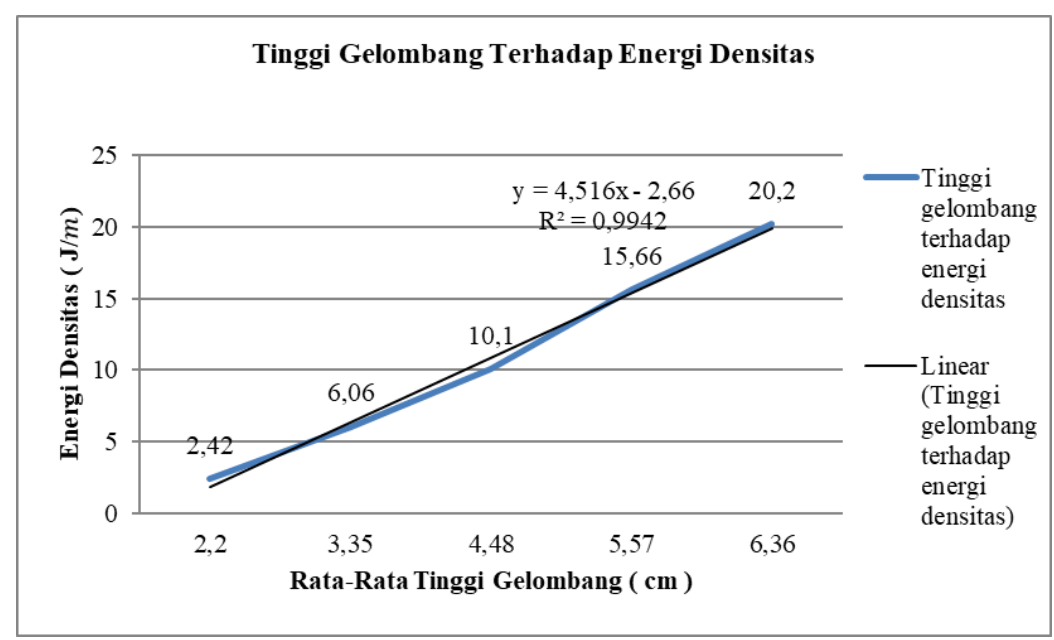

Gambar 7. Rata-Rata tinggi Gelombang Terhadap Energi Densitas

Pada Gambar 6 dan 7 diatas dapat di lihat bahwa besarnya energi yang di hasilkan dari gelombang buatan yang dipengaruhi oleh gerakan motor berbanding lurus dengan rata-rata tinggi gelombang pada prototype, hal ini dikarenakan rata - rata tinggi gelombang sangan mempengaruhi energi yang dihasilkan.

\section{KESIMPULAN}

Hasil perhitungan analisis data rata -rata tinggi gelombang $2,2 \mathrm{~cm}$ menghasilkan energi total sebesar 1,27 Joule serta energi densitasnya 2,42 Joule $/ \mathrm{m}^{2}$, pada rata - rata tinggi $3,35 \mathrm{~cm}$ menghasilkan energi total sebesar 5,06 Joule serta energi densitasnya $6,06 \mathrm{Joule} / \mathrm{m}^{2}$, pada rata - rata tinggi $4,48 \mathrm{~cm}$ menghasilkan energi total sebesar 10,98 Joule serta energi densitasnya $10,10 \mathrm{Joule} / \mathrm{m}^{2}$, pada rata - rata tinggi 5,57 cm menghasilkan energi total sebesar 20,71 Joule serta energi densitasnya 15,66 Joule/ $\mathrm{m}^{2}$, pada rata - rata tinggi $6,46 \mathrm{~cm}$ menghasilkan energi total sebesar 30,02 Joule serta energi densitasnya $20,20 \mathrm{Joule} / \mathrm{m}^{2}$, hasil yang didapatkan berbanding lurus dengan rata - rata tinggi gelombang, dimana semakin besar rata - rata gelombang, maka periode gelombang, panjang gelombang, kecepatan gelombang, energi total serta energi densitasnya juga semakin besar. Perancangan mekanisme pada analisis potensi energi gelombang air laut menggunakan teknologi Oscillating Water Column dimana sebagai bahan utamanya adalah kaca yang memiliki ukuran panjang $80 \mathrm{~cm}$ dengan lebar $40 \mathrm{~cm}$ menggunakan 2 chamber. Dengan menggunakan motor power window sebagai pembentuk gelombang buatan dari hasil putaran motor. 


\section{REFERENSI}

[1] J. Twidell, Renewable Energy Resources, The Second. Prancis: Taylor and Francis e-Library, 2006.

[2] A. Prastiantomo, "RANCANG BANGUN MINIATUR PEMBANGKIT GELOMBANG LAUT ( OMBAK )," 2014.

[3] D. Wipadma, Shintawati, and A. Supardi, "Studi Potensi Pembangkit Listrik Tenaga Gelombang Laut Sistem Oscillating Water Column (OWC) di Kelautan Indonesia," 2019.

[4] M. Khoirul, R. Febri, S. Sarwito, and R. Kusuma, "Perancangan Prototype Pembangkit Listrik Tenaga Gelombang Laut Tipe Oscilating Water Column di Pantai Bandealit Jember," vol. 3, no. 1, pp. 138-141, 2014.

[5] U. Indonesia, S. R. Utami, F. Teknik, P. Studi, T. Elektro, and K. T. Listrik, "GELOMBANG LAUT DENGAN MENGGUNAKAN SISTEM OSCILATING WATER COLUMN ( OWC ) DI TIGA PULUH WILAYAH KELAUTAN INDONESIA GELOMBANG LAUT DENGAN MENGGUNAKAN SISTEM OSCILATING WATER COLUMN ( OWC ) DI TIGA PULUH WILAYAH KELAUTAN INDONESIA,” 2010.

[6] P. Jumlah, S. Turbin, W. Dan, and V. Gelombang, "Digital Digital Repository Repository Universitas Universitas Jember Jember Digital Digital Repository Repository Universitas Universitas Jember Jember,” 2017.

\section{BIOGRAFI PENULIS}

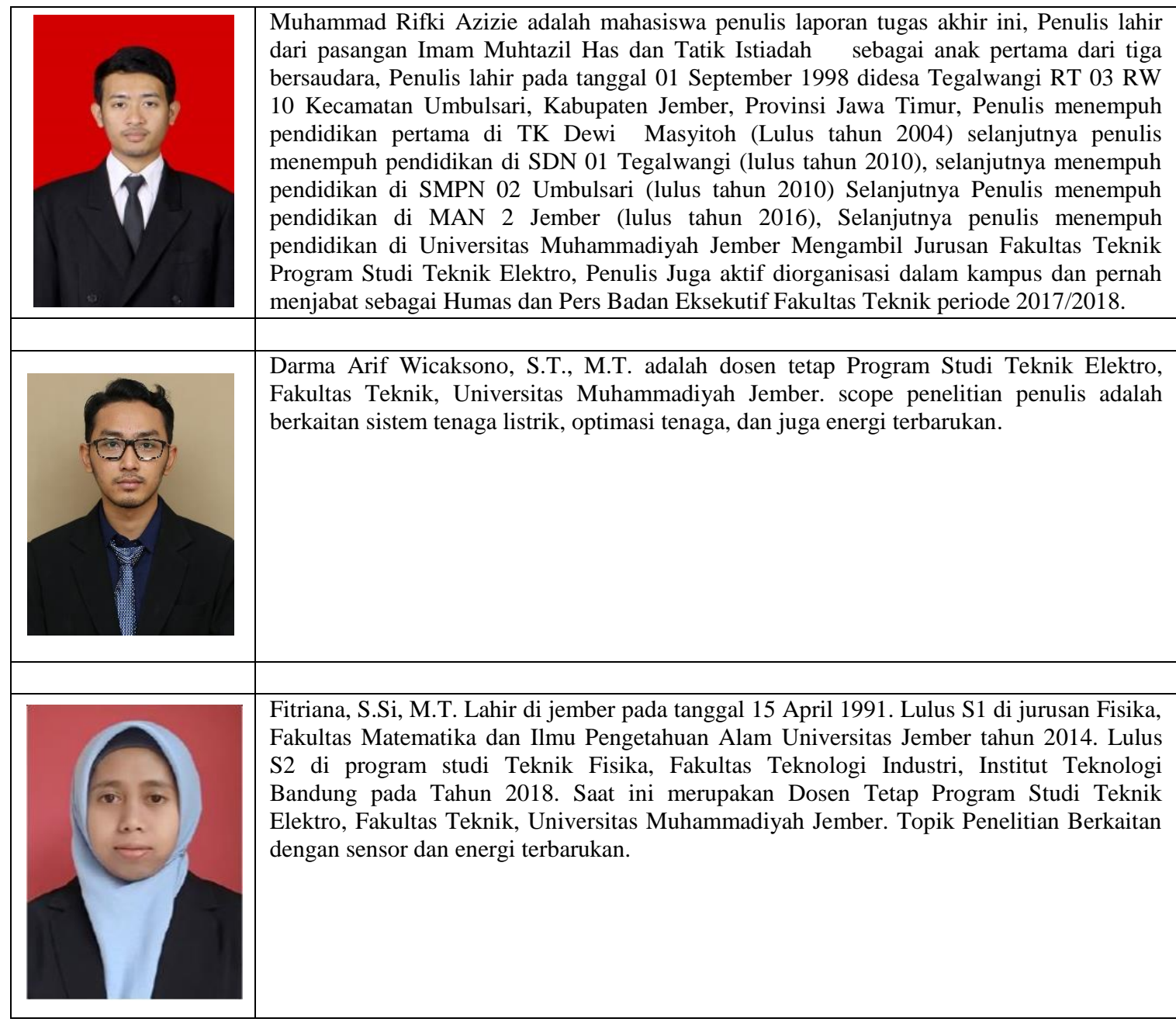

